https://doi.org/10.15407/scine17.05.042

SMIRNOV, O. M. (https://orcid.org/0000-0003-1173-976X),

NARIVSKIY, A. V. (https://orcid.org/0000-0002-1596-6401),

SMIRNOV, E. N. (https://orcid.org/0000-0002-4948-1031),

SEMENKO, A. Yu. (https://orcid.org/0000-0002-0448-1636),

and VERZILOV, O. P. (https://oreid.org/0000-0003-0463-5006)

Physico-Technological Institute of Metals and Alloys, the NAS of Ukraine (PTIMA NASU),

34/1, Acad. Vernadsky Blvd, Kyiv, 03142, Ukraine,

+380 44 4243515, metal@ptima.kiev.ua

\title{
INCREASING THE DOSING ACCURACY OF MAGNETODYNAMIC FOUNDRY EQUIPMENT
}

Introduction. The problem of combining continuous monitoring of the main informative process parameters (mass, temperature, melt consumption) and control of the pouring process is relevant for almost all filling devices today.

Problem Statement. The development of pouring accuracy methods, particularly for small-dose pouring is an important task for the foundry industry.

Purpose. The purpose is to study the dependences of the flow characteristics of the magnetodynamic equipment on the supplied voltage in various conditions of its operation.

Materials and Methods. Physical modelling has been applied for the study of dosing accuracy for small doses in the range of $1.5-3 \mathrm{~kg}$.

Results. The coefficient of the numerical dependence of instantaneous mass flow consumption of a modeling fluid in the trough on the instantaneous mass of a modeling fluid in the trough has been established based on experimental studies with the use of a physical model of magnetodynamic device (MDD). The studies of filling doses within the range from 1.5 to $3 \mathrm{~kg}$ have shown that this coefficient corresponds to the range of the electromagnet supply voltage from 12.3 to $16.3 \mathrm{~V}$. There have been determined the efficient range of the poured-metalmass to instantaneous-mass-flow-consumption ratio in the course of casting (2.20-2.25) and the corresponding range of the MDD electromagnet supply voltage to minimize the effect of jet pulsations on the dosing accuracy by reducing their amplitude. The dosing error does not exceed $1.5 \%$ by dose weight in the case of pouring small portions $(1.5-3 \mathrm{~kg})$.

Conclusions. A new technical solution for MDD with an inclined weighting trough of a conventional design has been developed based on the electromagnetic transfer of a force proportional to the instantaneous melt mass in the trough. The implementation of this solution makes it possible to reduce the number of strain gauge power sensors for the instantaneous measurement of the melt mass, from four sensors installed under the melting pot of the MDD prototype to one placed directly under the trough.

Keywords: casting installation, melt, force measuring sensor, dosing, flow consumption, and casting.

Citation: Smirnov, O. M., Narivskiy, A. V., Smirnov, E. N., Semenko, A. Yu., and Verzilov, O. P. Increasing the Dosing Accuracy of Magnetodynamic Foundry Equipment. Sci. innov. 2021. V. 17, no. 5. P. 42-49. https://doi.org/10.15407/scine17.05.042 
For a long time, aluminum was one of the most valuable metallurgical resources in the world. Today, given the forecasts that its global consumption will grow up to 120 million tons by 2025, it is the second most widespread metal in the world after steel. Such a high demand for aluminum influences the specifics of foundry. In 2017, global aluminum production grew by $6 \%$, largely due to automobile industry, aerospace industry, engineering, and packaging. As the requirements of environmental legislation get tougher, the need to reduce fuel consumption and $\mathrm{CO}_{2}$ emissions from cars has been becoming increasingly important. New more environment friendly cars should be lighter, therefore, for the production of some components (especially large structural parts), it is advisable to choose aluminum instead of heavier steel. Therefore, by 2022, the aluminum content in the average car will increase by $100 \mathrm{~kg}$, as the aluminum parts will replace the heavier components. By 2025, the use of aluminum parts in automobiles around the world will grow twice (from $12 \%$ to $25 \%$ ), up to 30 million tons [1-5].

The rapidly growing world market of complex molded aluminum parts requires perfect synchronization of equipment for aluminum working, including devices for melting, holding, dosing, casting, and processing.

Complex structural automobile components made of aluminum are difficult to cast accurately and to handle well. This means that in the field of casting, quality gradually takes precedence over quantity, and this requires specialized sophisticated equipment. To raise the stakes, foundries shall invest in equipment and innovations.

The problem of combining continuous monitoring of the main informative technological parameters (mass, temperature, mass flow consumption) and control over the pouring process is relevant for almost all filling devices today. Its solution will improve the reproducibility of the results and the efficiency of melt processing, optimize the operation of such equipment, reduce energy consumption, increase the competitiveness of multifunctional foundry equipment $[4,5]$.
Improving the quality of metal products is inextricably linked to the capabilities of casting and dosing equipment used in foundry manufacturing processes. The practice of operating such equipment has shown that high results may be achieved by using multifunctional magnetodynamic devices (MDD) developed by the PTIMA NASU. They provide melting to the required chemical composition, off-furnace treatment before casting into a mold or other metal receiver, as well as highquality casting of melts [6-8].

Despite the advantages and simplicity of timeor volume-based dosing methods, the most accurate one is the weight-based one. Particularly effective technique is the combination of supplying the melt to the casting molds with the use of MDD and the continuous monitoring of its variable mass in the course of casting [9]. This approach allows implementing the discrete dosing method with pouring the melt mass directly from the MDD into the mold.

The researches and patents on inventions, which dealt with solving this problem and were published over the past two decades mainly contained new developments in the field of automated foundry equipment for metered casting of metal into single and permanent casting molds. The analysis of similar magnetodynamic equipment, according to GOST 30573-98, has shown that its main parameters include:

- metal consumption in the course of casting, which corresponds to the useful mass of the bath load, varies from $0.3-0.6 \mathrm{~kg}$ to $2.5-3.5 \mathrm{~kg} / \mathrm{s}$;

- dose mass ranges from $0.3-1.2 \mathrm{~kg}$ to $30-120 \mathrm{~kg}$;

- dosing error from 4-5\% for a minimum dose weight; up to $1.5-2.5 \%$ for a maximum dose weight (the smaller is the given dose, the higher is the error).

At the second stage, similar equipment was taken from leading world manufacturers, such as: $A B B$ (Switzerland-Sweden), Otto Junker (Germany), and Siemens VAI (Austria) [10-12]. The consumption characteristics of the existing equipment for the pretreatment and casting of metals and alloys with the existing MDD are compared in Table 1. 


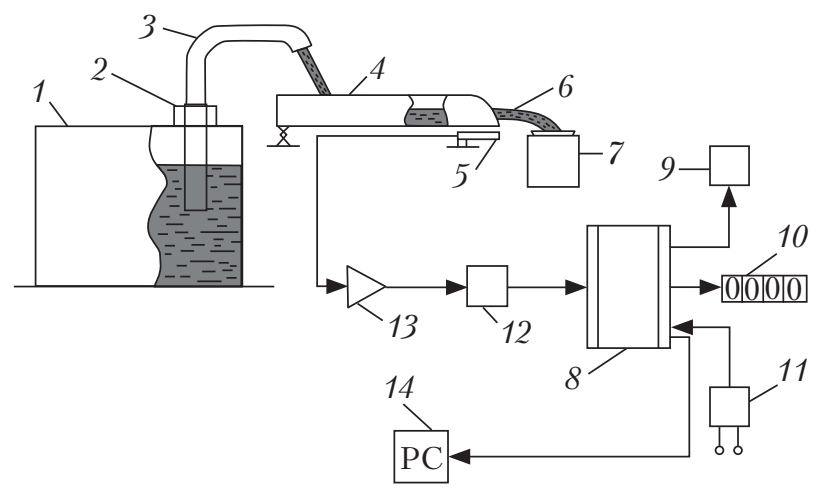

Fig. 1. The structural and functional diagram of the physical model: 1 - tank with a modeling fluid; 2 - electric pump; 3 - exhaust pipe; 4 - drain trough; 5 - strain gauge resistor; 6 - modeling fluid; 7 - receiving tank; 8 - microprocessor control unit for the discrete dosing process; 9 - control unit; 10 - digital indicator; 11 - power unit; 12 - analog-to-digital converter; 13 - amplifier; 14 - personal computer (PC)

The high cost and complexity of practical tests to modernize the existing equipment and to develop the new one for producing high-quality metal products, especially at the metallurgical component stage, have brought the physical and mathematical modeling methods to the forefront. They can be an effective tool in the hands of an engineer for the quick development of advanced design technologies and the optimization of the resulting solutions according to the criteria of maximizing quality and minimizing energy and resource costs $[13,14]$.

Improving the accuracy of discrete casting is associated with a decrease in the harmful effects of external and internal destabilizing factors that lead to variations or inconsistency with the set value of the main technological parameters of the casting process. One of such factors that have an adverse impact on the stability of the casting pro- cess, namely, the dosing accuracy, is the pulsation of the pouring melt jet because of the formation of vortex hydrodynamic structures in the working area of the casting equipment.

The purpose of this research is to study the dependences of the flow characteristics of the magnetodynamic equipment on the supplied voltage in various conditions of its operation.

Experimental researches have been carried out on a physical model of MDD for aluminum alloys. A new technical solution has been developed for MDD with a weighting inclined trough of a conventional design [15], based on the electromagnetic transfer of a force proportional to the instantaneous melt mass in the trough. The implementation of this solution makes it possible to reduce the number of strain gauge power sensors for the instantaneous measurement of the melt mass, from four sensors placed under the melting pot of the prototype MDD to the one mounted directly under the trough.

In order to achieve this goal, the following tasks have been solved:

- the development of experimental research methods for a physical model of a casting machine with a weighting drain trough;

- the study of the dependence of the flow consumption characteristics in different operating MDD modes on the voltage applied;

- the determination of conditions for increasing the dosing accuracy for small doses in the range of $1.5-3 \mathrm{~kg}$.

Presentation of the main material. In the wellknown technical solutions, for obtaining continuous information about variable melt mass, MDD is installed on a platform of scales of various con-

Table 1. Consumption Characteristics of the Existing Equipment for the Pretreatment and Casting of Metals and Alloys

\begin{tabular}{|l|c|c|c|c|c|}
\hline \multicolumn{1}{|c|}{ Parameter } & $\begin{array}{c}\text { Existing MDD } \\
\text { (mixer \& batcher) }\end{array}$ & $\begin{array}{c}\text { Robotic filling } \\
\text { devices }\end{array}$ & $\begin{array}{c}\text { Induction } \\
\text { duct furnaces }\end{array}$ & $\begin{array}{c}\text { Low pressure casting } \\
\text { machines (pneumatic) }\end{array}$ & $\begin{array}{c}\text { Required } \\
\text { values }\end{array}$ \\
\hline Mass flow, kg/s & $0.3-10.0$ & - & - & to 5.0 & $0.05-15$ \\
Dose, $\mathrm{kg}$ & $2-150$ & $0.3-3.0$ & - & $2-150$ & $0.5-500$ \\
Dosing accuracy, \% & 2.0 & 3.0 & - & 3.0 & $1 \%$ \\
The melt flow velocity, m/s & $0-5$ & - & to 1.0 & - & $0-10$ \\
\hline
\end{tabular}


figurations [3]. Mainly, electromechanical scales based on strain gauge force-measuring sensors are used [7]. To improve the accuracy of weighing and dosing when pouring the melt from the MDD into molds, a new technical solution has been developed. It implements continuous measurement of the melt mass without the use of platform scales. To determine the effectiveness of its implementation, a physical model of MDD of an improved design for aluminum alloys has been developed (Fig. 1).

According to this solution, the strength-measuring strain gauge sensor is located directly under the MDD drain trough (Fig. 2), and the force created by the mass of metal in the trough influences its power input.

The model includes: a tank with a modeling fluid (water), which is set on a fixed platform; an electric pump; an inclined trough of a conventional design; an electromagnet; a strain gauge sensor (with a system for measuring the signal of the output sensor); 0.03 class electronic scales (NPV is $6 \mathrm{~kg}$ ); a dial indicator head; a set of reference weights of the $4^{\text {th }}$ category (weighing $0.5 ; 1.0 ; 5.0$; $10.0 \mathrm{~kg}$ ); a control unit; a power unit; a receiving tank; and a personal computer.

Before experimental studies, the following preparation works are carried out:

- arrangement of power supply to the control unit and check of the operation of circuit elements operation;

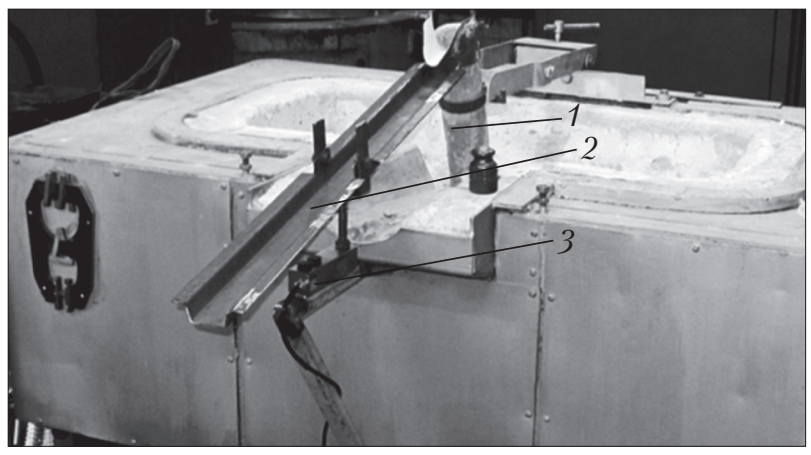

Fig. 2. Photo of a prototype of the technical solution: $1-$ exhaust pipe; 2 - drain trough; 3 - strain gauge sensor

- verification and setting of the measuring scheme of the dispenser;

- setting up of the load-measuring scheme in general and metering of the dispenser in the ranges of 1, 2, and $10 \mathrm{~kg}$ (5 measurements shall be carried out in each range).

The tank filled with water is installed on a fixed platform and equipped with an electric pump connected to the control unit. The pump outlet pipe is located above the drain trough, one end of which is pivotally set on a fixed base, and the other one is attached to the power input of the doublebend tensor resistor sensor also placed on a fixed base. The sensor output through the amplifier and the analog-to-digital converter is connected to the microprocessor control unit for discrete dosing of the modeling fluid into the receiving tank. Power to the dosing process control system is

Table 2. The MDD Flow Characteristics

\begin{tabular}{|c|c|c|c|c|c|c|c|c|}
\hline \multirow{2}{*}{$\mathrm{U}, \mathrm{V}$} & \multicolumn{3}{|c|}{$\mathrm{Q}, \mathrm{g} / \mathrm{s}$} & \multirow{2}{*}{$\begin{array}{l}\mathrm{Qcp} \\
\mathrm{g} / \mathrm{s}\end{array}$} & \multirow{2}{*}{$\sigma$} & \multirow{2}{*}{$v, \%$} & \multirow{2}{*}{ K } & \multirow{2}{*}{$\mathrm{m}_{\mathrm{vis}}$} \\
\hline & 1 & 2 & 3 & & & & & \\
\hline 10 & 65.2 & 65.9 & 65.0 & 65.4 & 0.46 & 0.7 & 1.98 & 0.033 \\
\hline 12.3 & 84.3 & 80.7 & 80.4 & 81.8 & 2.17 & 2.6 & 2.23 & 0.036 \\
\hline 14 & 100.4 & 99.9 & 99.8 & 100.0 & 0.35 & 0.3 & 2.19 & 0.045 \\
\hline 14.5 & 109.3 & 106.8 & 105.4 & 107.2 & 1.97 & 1.8 & 2.24 & 0.048 \\
\hline 16.3 & 118.4 & 118.6 & 112.8 & 116.6 & 3.32 & 2.8 & 2.26 & 0.051 \\
\hline 16.5 & 122.0 & 115.2 & 112.4 & 116.5 & 4.90 & 4.2 & 2.03 & 0.057 \\
\hline 18.5 & 136.9 & 134.6 & 132.7 & 134.7 & 2.13 & 1.6 & 2.35 & 0.057 \\
\hline 20.2 & 148.9 & 145.9 & 140.0 & 145.2 & 4.05 & 2.7 & 1.77 & 0.079 \\
\hline 20.5 & 148.3 & 147.5 & 146.1 & 147.3 & 1.10 & 0.7 & 2.27 & 0.066 \\
\hline
\end{tabular}



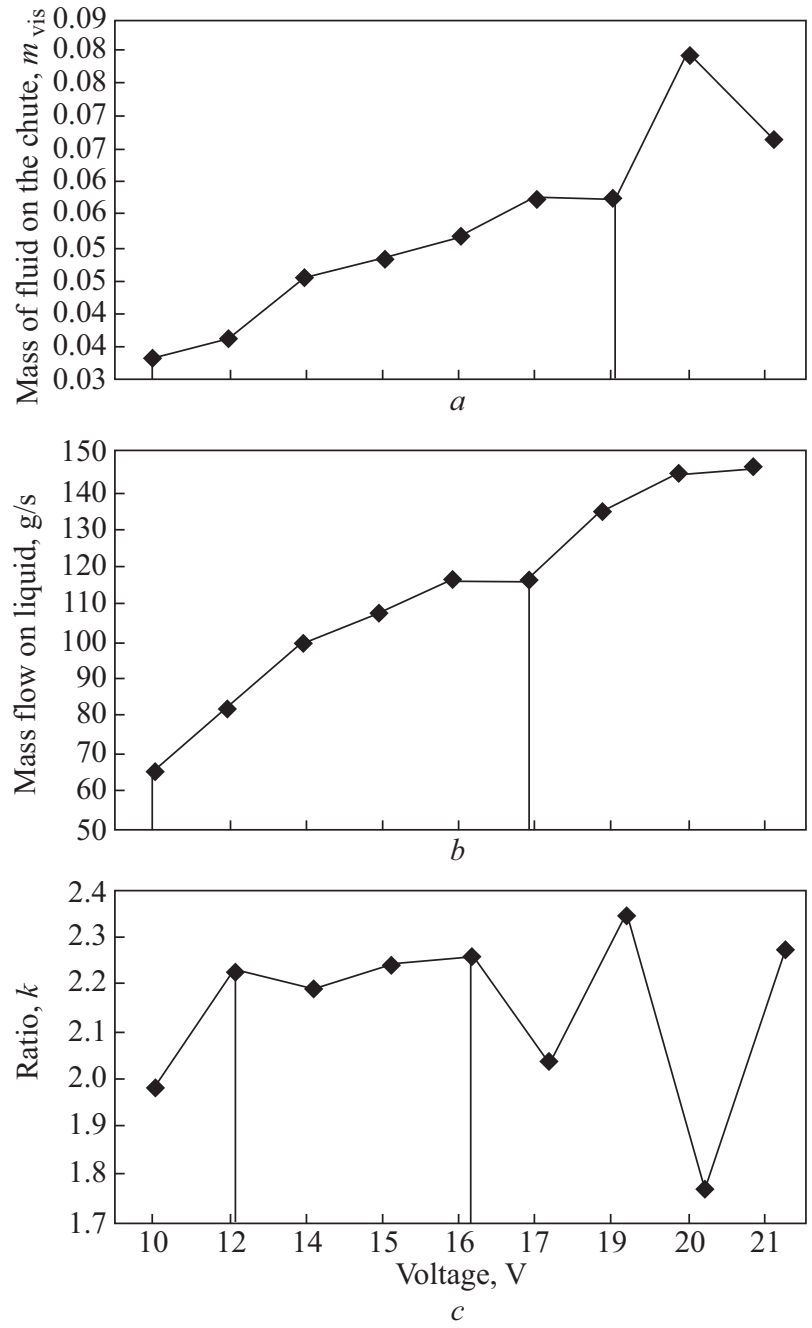

Fig. 3. Study of the criteria for determining the optimal voltage of the device

supplied from the power supply unit connected to a $220 \mathrm{~V}$ AC voltage system. The pump is controlled by the control unit connected to the power unit. The dose is indicated with the use of a digital indicator. The physical model also includes a personal computer designed to study the dosing process dynamics.

The physical model works in the following way. In the initial state, the tank is filled with modeling fluid, the control system is connected to the network and is in sleep mode, and zeros in all digits are displayed on the indicator. Upon the command of the control unit, the pump drive is activated and the modeling fluid starts flowing to the drain trough through the pipeline to the receiving tank. In this case, a signal $U_{m}$ appears at the sensor's power input, which is proportional to the instantaneous mass $m$ of the modeling fluid in the trough. The signal $U_{m}$ is integrated in the microprocessor unit and as the drained mass of liquid in the receiving tank reaches the set value $m_{\mathrm{d}}$, the pump drive is off. The next doses of liquid are poured in the same way.

Voltage is the parameter to be controlled in the course of dosing [3-5, 9], therefore, the objective of these studies is to determine its effective range. To this end, with the help of the developed technique and the physical model of the MDD, given the observation of the modeling fluid jet hydraulic parameters, there have been obtained and recorded the following data (Table 2).

This approach is justified by the fact that the dose may be filled with a high accuracy only at a constant flow consumption and, accordingly, with a laminar flow of the jet in the drain trough. The experimental data is shown in Table 2, where $U$ is voltage, $\mathrm{V} ; Q$ is the instantaneous mass flow consumption in the trough, $\mathrm{g} / \mathrm{s} ; Q_{\mathrm{av}}$ is the average mass flow consumption of the modeling fluid, $\mathrm{g} / \mathrm{s}$; $\sigma$ is standard deviation; $v$ is variation coefficient, $\% ; m_{\text {vis }}$ is the instantaneous mass of fluid in the trough (determined by the strain gauge sensor); $K$ is the coefficient of dependence of the instantaneous consumption of the modeling fluid on its instantaneous mass.

The data is recorded every $6 \mathrm{~s}$, within the voltage range from 10 to $20.5 \mathrm{~V}$ (three starts of the physical model). For each voltage value, the flow consumption of the modeling fluid is calculated by the formula:

$$
Q=m_{\partial} / t
$$

where $m_{\partial}$ is the mass of the modeling fluid dose for time interval $t$.

Further, to determine the effective voltage, the three dependences of the studied voltage parameters on the following criteria are used:

- the instantaneous mass of the modeling fluid in the trough $m_{\text {vis }}$;

- the instantaneous mass flow consumption of the modeling fluid in the trough $Q$; 
- for the third dependence, the coefficient $k$ is calculated; it shows the numerical dependence of $Q$ on $m_{\text {vis }}$;

$$
k=Q / m_{\text {vis }} \text {. }
$$

More detailed explanation with the use of graphic display is given in Fig. 3. It shows how the optimal voltage interval $U$ is determined with the criteria successively taken into account.

Fig. 3 shows that as voltage increases from 10 to $18.5 \mathrm{~V}$, the instantaneous mass gradually grows. As for the second parameter $Q$ (Pic. $3, b$ ), it has been shown that it gradually increases within a smaller voltage range, from 10 to $16.5 \mathrm{~V}$. Having introduced the coefficient $k$ (Fig. 3, c), we have determined the optimal voltage range: $U=12.3-16.3 \mathrm{~V}$.

At the third stage (Fig. 3, c), having introduced the coefficient $k$, we have shown that its effective range is from 2.2 to 2.25 . It has been confirmed by the minimization of the fluid jet pulsation effect on the metering accuracy through reducing their oscillation amplitude when pouring doses of $1.5-3 \mathrm{~kg}$.

Within the effective range of the obtained coefficient, the metal jet flow in the trough is laminar and constant; if its value is up to 2.2 , the jet is intermittent; if it exceeds 2.25 , the flow is turbulent, the jet is intermittent.

In general, the specific feature of the proposed method for increasing the accuracy of the melt dosing, as compared with the existing ones, is that for pouring small doses, the dosing error does not exceed $1.5 \%$, while the error of similar equipment for small doses is $4-5 \%$.

The use of the obtained coefficient in designing new filling equipment prototypes is the subject of the further research.
Conclusion. The coefficient of the numerical dependence of instantaneous mass flow consumption of a modeling fluid in the trough on the instantaneous mass of a modeling fluid in the trough has been established based on experimental studies with the use of a physical model of magnetodynamic device. The studies of filling doses within the range from 1.5 to $3 \mathrm{~kg}$ have shown that this coefficient corresponds to the range of the electromagnet supply voltage from 12.3 to $16.3 \mathrm{~V}$.

The research novelty is:

1. As a result of physical modeling, the optimal range of fluid flow in the weighting trough has been established. It helps to minimize the effect of jet pulsations on the metering accuracy by reducing their amplitude. In this case, the dosing error when filling 1.5-3 kg doses does not exceed $1.5 \%$, while the error of similar equipment for small doses is $4-5 \%$.

2. The developed design of the weighting trough allows increasing the reliability and accuracy of dosing the melt due to the lack of mechanical connection between the load sensor and the drain trough.

3. The proposed technical solution simplifies the equipment design, which positively affects the cost of foundry products and provides an economic effect while introducing into production.

Research funding. The research has been performed at the Physics and Technology Institute of Metals and Alloys of the NAS of Ukraine. The studies have been carried out as part of project NDR III-09-17-671 Development of the Research Framework for the Creation of New Highly Efficient Multifunctional Magnetodynamic Intermediate Ladles for Continuous Casting Processes.

\section{REFERENCES}

1. The International Aluminium Institute. Primary aluminium production. URL: http://www.world-aluminium.org/statistics/primary-aluminium-production/ (Last accessed: 14.05.2020).

2. Nath, J. (2018). Aluminum casting engineering guide. USA: ASM International. 316 p.

3. Wang, E. (2015, October). Progress of some techniques on electromagnetic metallurgy. Proceedings of the 8th International Conference on Electromagnetic Processing of Materials "EPM 2015", (October 12-16, 2015). Cannes, 3-6.

4. Grayson, J. (2016). Understanding Melting Furnace Economics and Optimizing Operations. Light Metal Age, $74(5), 2$.

5. Equipment for aluminium casting. URL: https://www.krownsa.com/equipment-for-aluminium-casting (Last accessed: 22.04.2020). 
6. Polyschuk, V. P., Cin, M. R., Gorn, R. K. (1989). Magnetodynamic pumps for liquid metals. Kyiv. [in Russian].

7. Dubodelov, V. I. (2008). Developments of the PTIMA NASU in the Field of Magnetohydrodynamics (History, State, and Prospects - Part II). P. 126-149 [in Russian].

8. Dubodelov, V., Smirnov, O., Louhenkilpi, S. (2015, October). Innovative combinations of MHD technologies and original electromagnetic devices for highly efficient casting on CCM. Proceedings of the 8th International Conference on Electromagnetic Processing of Materials "EPM 2015,. (October 12-16, 2015). Cannes, 621-624.

9. Slazhniev, M., Kizilova, A., Bogdan, K. (2015, October). Developing of pragmatic models of the ponderomotive interactions in magnetodynamic installations for aluminum alloys MDN-6A. Proceedings of the 8th International Conference on Electromagnetic Processing of Materials "EPM 2015,. (October 12-16, 2015). Cannes, 593-596.

10. Induction furnace technology and energy efficiency. URL: http://castingssa.com/induction-furnace-technology-andenergy-efficiency/ (Last accessed: 14.05.2020).

11. Qiang, W., Baokuan, L., Fumitaka, T. (2014). Modeling of a Thermo-Electromagneto-Hydrodynamic Problem in Continuous Casting Tundish with Channel Type Induction Heating. ISIJ International, 54(2), 311-320. https://doi. org/10.2355/isijinternational.54.311

12. Smirnov, O., Smyrnov, Y., Louhenkilps, S. (2017). Mathematical modeling of multiphase system in tundish of continuous casting machine: theory and experiments. Jornal of Chemical Technology and Metallurgy, 52(4), 711-717.

13. Haiyan, T., Luzhao, G., Guanghui, W. (2018). Hydrodynamic Modeling and Mathematical Simulation on Flow Field and Inclusion Removal in a Seven-Strand Continuous Casting Tundish with Channel Type Induction Heating. Metals, 8, 374-398. https://doi.org/10.3390/met8060374.

14. Dubodelov, V. I., Smirnov, A. N., Efimova, V. G., Kravchenko, A. V., Verzilov, A. P. (2018). Hydrodynamic and physicochemical processes in tundishes for continuous casting of steel. Kyiv [in Russian].

15. Dubodelov, V., Semenko, A., Bogdan, K., Goryuk, M. (2019). Development of Principles to Control the Processes of Continuous Casting of Alloys Using Magnetodynamic Equipment. Eastern-European Journal of Enterprise Technologie, 4(1(100)), 69-75. https://doi.org/10.15587/1729-4061.2019.172051.

Received 07.09.2020

Revised 22.12.2020

Accepted 29.03.2021

О. М. Смірнов (https://orcid.org/0000-0003-1173-976X),

А. В. Нарівський (https://orcid.org/0000-0002-1596-6401),

Є. М. Смірнов (https://orcid.org/0000-0002-4948-1031),

А. Ю. Семенко (https://orcid.org/0000-0002-0448-1636),

О. П. Верзілов (https://orcid.org/0000-0003-0463-5006)

Фізико-технологічний інститут металів та сплавів

Національної академії наук України (ФТІМС НАН України),

бульв. Вернадського, 34/1, Київ, 03142, Україна,

+380 444243515 , metal@ptima.kiev.ua

ПІДВИЩЕННЯ ТОЧНОСТІ ДОЗУВАННЯ

МАГНІТОДИНАМІЧНОГО ЛИВАРНОГО ОБЛАДНАННЯ

Вступ. Проблема поєднання безперервного контролю основних інформативних технологічних параметрів (маси, температури, масової витрати розплаву) та управління процесом заливання на сьогодні $є$ актуальною практично для всіх заливальних пристроїв.

Проблематика. Розробка методів точності розливу, зокрема при розливах малих об’ємів, є важливим завданням ливарної галузі.

Мета. Вивчення залежностей витратних характеристик магнітодинамічного обладнання від напруги, що подається, в різних режимах його роботи.

Матеріали й методи. Для вивчення точності дозування для малих доз в межах 1,5-3 кг застосовано фізичне моделювання.

Результати. Шляхом експериментальних досліджень на фізичній моделі магнітодинамічної установки встановлено коефіцієнт чисельної залежності миттєвого значення масової витрати моделюючої рідини на жолобі від миттєвого значення маси моделюючої рідини на жолобі. В рамках проведення досліджень для заливання доз масою 1,5-3 кг він 
відповідає діапозону напруги живлення електромагніта рівному 12,3-16,3 В. Визначено раціональний інтервал співвідношення маси разливаної порції металу та миттєвого значення масової витрати при іiі розливанні (2,20-2,25) i відповідний інтервал напруги живлення електромагніта МДУ з метою мінімізації впливу пульсацій струменя на точність дозування за рахунок зменшення їхньої амплітуди. Похибка дозування не перевищує 1,5\% від маси дози при розливанні малих порцій розплаву (масою 1,5-3 кг).

Висновки. Розроблено нове технічне рішення для магнітодинамічних установок з вагодозуючим похилим жолобом традиційної конструкції, засноване на передачі електромагнітним способом сили, пропорційної миттєвому значенню маси розплаву на жолобі. Реалізація такого рішення дає можливість зменшити кількість тензорезисторних силових датчиків для вимірювання миттєвого значення маси розплаву, з чотирьох, встановлених під тиглем прототипу МДУ, до одного, розміщеного безпосередньо під жолобом.

Ключові слова: заливальна установка, розплав, силовимірювальний датчик, дозування, витрата, виливок. 